\title{
Metastasis of Primary Colon Cancer to the Breast - Leave Well Alone
}

\author{
Ludger Barthelmes $^{a} \quad$ James S. Simpson ${ }^{a} \quad$ Anthony G. Douglas-Jones ${ }^{b} \quad$ Helen M. Sweetland ${ }^{a}$ \\ ${ }^{a}$ Department of Surgery, ${ }^{\mathrm{b}}$ Department of Pathology, School of Medicine, Cardiff University, UK
}

Key Words

Colon cancer · Metastasis · Breast neoplasm

\section{Summary}

Background: Metastasis to the breast is rare. Its management differs from that of primary breast cancer, as illustrated by this case of a colonic metastasis to the breast. Case Report: A 78-year-old woman presented with a breast lump 16 months after a palliative colonic resection for an obstructing colon cancer (T4 N0 M1). Core biopsy of the breast lump revealed morphological features identical to the original bowel cancer. In view of her progressive metastatic disease, the breast lump was simply observed. She passed away 4 months later from advanced intra-abdominal carcinomatosis. Discussion: There are 19 cases of colonic metastasis to the breast in the literature. In the literature, colonic metastases to the breast are usually excised. Conclusion: Excision of a colonic metastasis to the breast can be avoided if the patient's life expectancy is short.

\section{Introduction}

Most breast cancers are primary breast malignancies. Metastasis to the breast is rare. Its management differs from that of primary breast malignancies, as illustrated by this case of a colonic metastasis to the breast.

\author{
Schlüsselwörter \\ Kolonkarzinom · Metastasierung · Neoplasie der Brust
}

\section{Zusammenfassung}

Hintergrund: Metastasierung in die Brust ist selten. Ihre Behandlung unterscheidet sich von der eines primären Mammakarzinoms, wie hier für den Fall der Metastasierung eines Kolonkarzinoms in die Brust beschrieben wird. Fallbericht: Eine 78-jährige Frau stellte sich 16 Monate nach einer palliativen Kolonresektion aufgrund eines obstruktiven Kolonkarzinoms (T4 NO M1) mit einem Knoten in der Brust vor. Eine Hohlnadelbiopsie des Knotens zeigte identische Strukturen zu denen des ursprünglichen Darmkrebses. In Anbetracht des fortgeschrittenen metastatischen Krankheitsstadiums wurde der Knoten in der Brust der Patientin nur beobachtet. Sie verstarb 4 Monate später an den Folgen der fortgeschrittenen intraabdominalen Karzinomatose. Diskussion: In der Literatur werden 19 Fälle von Metastasierung eines Kolonkarzinoms in die Brust beschrieben. In den in der Literatur beschriebenen Fällen werden die Kolonkarzinommetastasen in der Brust meist operativ entfernt. Schlussfolgerung: Die operative Entfernung von Kolonkarzinommetastasen in der Brust kann bei einer nur kurzen Lebenserwartung des Patienten vermieden werden.

\section{Case Report}

A 78-year-old woman was referred to the breast clinic with a lump in her left breast. Her past medical history included a palliative colonic resection for an obstructing transverse colon cancer (T4 N0) 16 months before. At that time, she was noted to have peritoneal tumor deposits on the posterior surface of the anterior abdominal wall (M1). Post-operatively, she had a 3-month course of capecitabine. Her carcinoembryonal antigen (CEA) level continued to rise over the following year from $3,443 \mathrm{ng} / \mathrm{ml}$ to

\begin{tabular}{ll}
\hline KARGER & @ 2010 S. Karger GmbH, Freiburg \\
Fax +497614520714 & Accessible online at: \\
Information@Karger.de & www.karger.com/brc \\
www.karger.com &
\end{tabular}


Fig. 1. Histological appearances of the core biopsy showing dissociated cells with abundant mucin (hematoxylin and eosin stain, magnification $\times 200)$. Occasional cells with signet ring morphology can be seen (magnified $\times 400$ - arrow, inset bottom

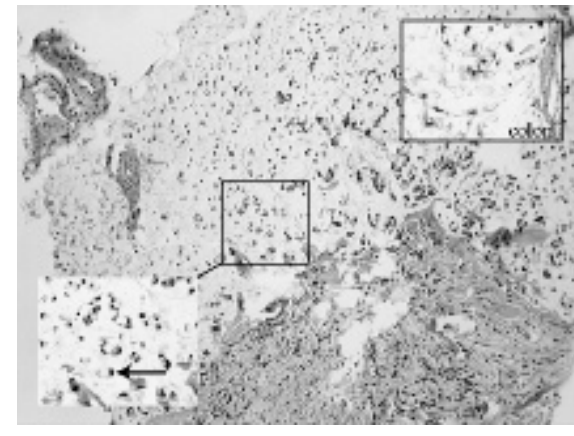
left). An identical tumor is seen in the original colon carcinoma (inset top right).

$6,200 \mathrm{ng} / \mathrm{ml}$. Her general condition, however, remained stable and she was independent and self-caring at the time of her referral to the breast clinic. On examination she had an ill-defined, mobile 1-cm lump at the lateral edge of the left axillary tail (P 4). Mammography revealed an indeterminate, lobulated mass in the same area, requiring histological clarification. Ultrasound-guided core biopsy revealed individual tumor cells and some cells with signet ring morphology (fig. 1, inset bottom left, arrow). The cells were separated by extracellular mucus. The appearances indicated a mucin-secreting adenocarcinoma but were not typical of large bowel carcinoma. The histology from the original large bowel carcinoma (previously excised) showed a mucin-secreting adenocarcinoma with identical morphological appearances to those in the core biopsy (fig. 1, inset top right). Immunohistochemistry of the core biopsy was negative for estrogen receptor and HER-2. The findings were compatible with metastatic large bowel carcinoma. In view of the rising CEA level, the patient underwent a computed tomography (CT) while awaiting the outcome of the investigation of her breast lump. This showed progressive peritoneal disease, but no liver or lung metastasis. As tumor progression was halted with a 3-month course of capecitabine at presentation and she was symptom free despite radiological evidence of progression, it was decided to re-institute the same chemotherapy regimen of oral capecitabine. Regarding the breast lump, it was decided not to surgically intervene and simply observe. She passed away 4 months later from advanced intra-abdominal carcinomatosis.

\section{Discussion}

Metastasis to the breast is uncommon, even more so metastasis of colon cancer to the breast. The latest review in 2004 identified 8 cases [1]. Searching Medline, including the nonEnglish literature, and hand-searching the references, we identified a further 11 cases including our own (table 1). 3 of the 19 patients presented synchronously, i.e., the diagnosis of

Table 1. Colon metastasis to the breast

\begin{tabular}{|c|c|c|c|c|c|c|}
\hline Author & $\begin{array}{l}\text { Age, } \\
\text { years }\end{array}$ & Gender & $\begin{array}{l}\text { Time from diagnosis of } \\
\text { primary colon cancer to } \\
\text { detection of breast } \\
\text { metastasis }\end{array}$ & $\begin{array}{l}\text { Stage of } \\
\text { colon } \\
\text { cancer }\end{array}$ & $\begin{array}{l}\text { Treatment of breast } \\
\text { metastasis }\end{array}$ & $\begin{array}{l}\text { Survival/observation } \\
\text { after detection of } \\
\text { breast metastasis }\end{array}$ \\
\hline McIntosh IH 1976 [8] & 44 & $\mathrm{~F}$ & 1 month & - & excision biopsy & 4 months (observed) \\
\hline \multirow[t]{2}{*}{ Lear PA 1980 [9] } & 30 & $\mathrm{~F}$ & 10 months & - & & 6 years (observed) \\
\hline & 67 & $\mathrm{M}$ & 1 year & Dukes B & mastectomy & - \\
\hline Nielsen M 1981 [10] & 59 & - & 6 months & - & - & 4 months \\
\hline \multirow[t]{2}{*}{ Alexander HR 1989 [11] } & 68 & - & 2 years & - & - & 6 months \\
\hline & 28 & $\mathrm{~F}$ & 11 months & $\mathrm{T} 4 \mathrm{~N} 2$ & $\begin{array}{l}\text { excision: } 2 \text { further ipsi- } \\
\text { + contralateral recurrences }\end{array}$ & 4 years (deceased) \\
\hline Bhirangi KS 1997 [2] & 86 & $\mathrm{~F}$ & synchronous & Dukes B & $\begin{array}{l}\text { wide local excision + axillary } \\
\text { node clearance (pre-op } \\
\text { diagnosis - primary breast) }\end{array}$ & 1.5 years (observed) \\
\hline Bruscagnin A 1997 [12] & 68 & $\mathrm{M}$ & synchronous & - & excision & - \\
\hline Scholz C 1998 [13] & 42 & $\mathrm{~F}$ & synchronous & - & observation & 4 months (deceased) \\
\hline Muttarak M 1998 [14] & 36 & $\mathrm{~F}$ & 1 year & - & - & - \\
\hline Lal RL 1999 [2] & 69 & $\mathrm{~F}$ & 1 year & T3 N0 & $\begin{array}{l}\text { wide local excision (pre- } \\
\text { opdiagnosis primary breast), } \\
\text { developed skin recurrence }\end{array}$ & 4 months (deceased) \\
\hline Ozakyol AH 2000 [15] & 42 & $\mathrm{~F}$ & 6 months & - & excision & 6 months (observed) \\
\hline Sironi M 2001 [16] & 66 & $\mathrm{~F}$ & 10 years & - & $\begin{array}{l}\text { continuation of } \\
\text { chemotherapy }\end{array}$ & - \\
\hline Oksuzoglu B 2003 [17] & 52 & $\mathrm{~F}$ & 20 months & Dukes C & biopsy & $\begin{array}{l}2 \text { months (observed - } \\
\text { widespread metastasis } \\
\text { at last observation) }\end{array}$ \\
\hline De Bobadilla 2004 [1] & 40 & $\mathrm{~F}$ & 4 years & Dukes C & mastectomy & 6 months (observed) \\
\hline Mihai R 2004 [18] & 53 & $\mathrm{~F}$ & 5 years & Dukes B & wide local excision & - \\
\hline Wakeham NR 2008 [19] & 45 & $\mathrm{~F}$ & 2 years & Dukes C & observation & - \\
\hline \multirow[t]{2}{*}{ Present case } & 74 & $\mathrm{~F}$ & 2 months & Dukes C & observation & - \\
\hline & 79 & $\mathrm{~F}$ & 1 year 4 months & T4 N0 M1 & observation & 4 months (deceased) \\
\hline
\end{tabular}


the metastasis to the breast coincided with the diagnosis of the colonic primary. Most patients - as ours - presented with a breast lump some time after diagnosis of the colon cancer (median 15 months, range 1 month to 10 years). The primary colonic tumor had lymph node involvement in 5 of 10 cases. Follow-up of the reported cases ranged from 4 months to 4 years (mean 15 months). Of 12 patients with documented follow-up, 5 died or had advanced disease at the last follow-up. Regarding treatment of the breast lump, all authors advise against extensive resection, but in the literature, most breast lumps have been excised. This is understandable if the lump is mistaken for a primary breast cancer, as reported twice $[2,3]$. Usually, bowel cancer precedes the development of the metastasis in the breast, alerting the clinician of the possibility of a colonic metastatic deposit within the breast. The patient's history, prompting histological comparison between the core biopsy of the breast with the original bowel cancer, usually secures the diagnosis and prevents the breast lump from being mistaken for a primary breast carcinoma. In the UK, with a non-operative breast cancer diagnosis rate of $94 \%$ for screendetected breast cancers [4], surgical excision is not normally required to reach a diagnosis, neither in the symptomatic setting where triple assessment - clinical examination, imaging (mammography/ultrasound) and core biopsy - is standard practice. Surgical excision of the metastasis from the breast is not without complications and has led to recurrence of the metastasis in the skin of the breast [3]. Seeding of colon cancer cells to the skin is a well-recognized complication of laparoscopic colon cancer surgery [5]. We elected not to operate on our patient and simply observed the breast lump. She was unlikely to develop uncontrollable chest wall disease, given her short life expectancy. Oral capecitabine, which was prescribed for palliative chemotherapy, may have further slowed down the growth of our patient's metastasis in the breast [6]. Axillary lymph node involvement has only been reported when the origin of the metastasis to the breast was from a malignant melanoma [7]. There was no axillary lymph node involvement in the case where treatment proceeded for a presumed primary breast cancer [2].

\section{Conclusion}

In view of the short life expectancy and the risk of seedling tumor cells to the skin, surgical excision may be avoidable in most patients presenting with colonic metastasis to the breast. There is no role for axillary surgery.

\section{Conflict of Interest}

The authors declare that they have no conflicts of interest.

\section{References}

1 de Bobadilla LF, Villanueva LG, Collado A, de Juan M, Rojo A, Perez R, Lisa J, Aguilera E, Mena A, Gonzales-Palacios A: Breast metastasis of primary colon cancer. Rev Esp Enferm Dig 2004;96: 415-417; 418-419.

2 Bhirangi KS, Pinto DJ, Crosbie JJ: Solitary breast metastasis from carcinoma of colon. Ulster Med J 1997;66:138-139.

3 Lal RL, Joffe JK: Rectal carcinoma metastatic to the breast. Clin Oncol 1999;11:422-423.

4 An audit of screen-detected breast cancers for the year of screening April 2006 to March 2007. NHS Breast Screening Programme and Association of Breast Surgery at BASO. www.cancerscreening. nhs.uk/breastscreen/publications/baso2006-2007. pdf, accessed on 16.06.2008.

5 Curte MJ: Port site metastases. Am J Surg 2004;187: 705-712.

6 Rossi D, Alessandroni P, Catalano V, Giordani P, Fedeli SL, Fedeli A, Baldelli AM, Casadei V, Ceccolini M, Catalano G: Safety profile and activity of lower capecitabine dose in patients with metastatic breast cancer. Clin Breast Cancer 2007;7:857-860.
7 Plesnicar A, Kovac V: Breast metastases from cutaneous melanoma: a report of three cases. Tumori 2000;86:170-173.

-8 McIntosh IH, Hooper AA, Millis RR, Greening WP: Metastatic carcinoma within the breast. Clin Oncol 1976;2:393-401.

9 Lear PA, Jackaman FR: Carcinoma of the rectum with metastasis in the male breast. J R Coll Surg Edinb 1980;25:246-247.

10 Nielsen M, Andersen JA: Metastases to the breast from extramammary carcinomas. Acta Pathol Microbiol Scand 1981;89:251-256.

11 Alexander HR, Turnbull AD, Rosen PP: Isolated breast metastases from gastrointestinal carcinomas. J Surg Oncol 1989:42:264-266.

12 Bruscagnin A: A case of male breast metastasis from adenocarcinoma of the colon. Radiol Med 1997;93:463-464.

13 Scholz C, Degen KW: Metastasis of a sigmoid carcinoma to the breast. Zentralbl Gynakol 1998;120: 518-520.
14 Muttarak M, Nimmonrat A, Chaiwun B: Metastatic carcinoma to the male and female breast. Australas Radiol 1998;42:16-19.

15 Ozakyol AH, Saricam T, Isiksoy S: Breast metastasis of primary colon cancer. Am J Gastroenterol 2000;95:2149.

16 Sironi M, Claren R, Delpiano C, Santangelo M, Spinelli M: Cytological findings of adenocarcinomas metastatic to the breast. Diagn Cytopathol 2001;24:369-372.

17 Oksuzoglu B, Abali H, Guler N, Baltali E, Ozisik Y: Metastasis to the breast from nonmammarian solid neoplasms: a report of five cases. Med Oncol 2003;20:295-300.

18 Mihai R, Christie-Brown J, Bristol J: Breast metastases from colorectal carcinoma. Breast 2004;13: $155-158$.

19 Wakeham NR, Satchithananda K, Svensson WE, Barrett NK, Comitis S, Zaman N, Ralleigh G, Sinnett D, Shousha S, Lim AK: Colorectal breast metastases presenting with atypical imaging features. Br J Radiol 2008;81:e149-e153. 